\title{
STIMULATION OF OVULATION IN PSEUDOPREGNANT RATS BY CLOMIPHENE AND RELATED COMPOUNDS*
}

\author{
R. SGHWANTJE AND H.-D. TAUBERT \\ Abteilung für gynäkologische Endokrinologie, Universitäts-Frauenklinik, \\ Frankfurt am Main, Germany
}

(Received 20th August 1969, revised 9th March 1970)

\begin{abstract}
Summary. Female Wistar rats were made pseudopregnant by electrical stimulation of the uterine cervix and used as models for anovulation. Clomiphene, cyclofenil, epimestrol, and stilboestrol were administered either for 2-day periods at various times of pseudopregnancy, or continuously from Days 3 to 8 , or until mating had taken place. All compounds tested stimulated ovulation at certain dose levels, but continuous administration proved to be more effective than the limited treatment. Pregnancies occurred after treatment with all test substances with the exception of clomiphene.
\end{abstract}

\section{INTRODUCTION}

Previous reports concerning the effects of clomiphene and related compounds upon the reproductive system of the female rat have emphasized their inhibitory effect upon gonadotrophin release, ovulation and fertility. Contrary to this, it has been shown that under proper experimental conditions these compounds may stimulate the release of both FSH and LH from the rat pituitary. It was reported by Igarashi, Ibuki, Kubo, Kamioka, Yokota, Ebara \& Matsumoto (1967) that clomiphene injected subcutaneously (s.c.) brought about a significant rise of FSH- and LH-levels in the plasma of mature male rats. In confirmation, it has recently been shown that there is a dose-dependent decrease of hypothalamic FSH-RF content and a concomitant increase of plasma FSH following the intravenous injection of clomiphene (Baier \& Taubert, 1969a) and cyclofenil (Taubert \& Baier, 1969) into oophorectomized rats, whose pituitaries had been blocked by the administration of oestradiol and progesterone. A similar effect could be obtained when stilboestrol was used, but no response could be elicited by the administration of epimestrol (Baier \& Taubert, 1969b). Recent experiments have indicated that these compounds also affect the release of $\mathbf{L H}$ and of LH-RF (Taubert, Kessler, Busch \& Werner, 1970). Hohlweg \& Mayer (1970) were able to demonstrate the presence of corpora lutea in the ovaries of immature rats following single injections of 25 to $75 \mu \mathrm{g}$ of clomiphene; and Watnick, Tabachnik \& Neri (1966) and Watnick \& Neri (1968) could induce ovulation in the anovulatory, pseudopregnant rat by application of cyclofenil

* Presented in part at the All India Conference on Research in Reproduction and Fertility Control, Bombay, 21st to 26th February 1970. 
and stilboestrol, but not with clomiphene. Therefore, it appeared to be of interest to examine whether or not it would be possible to stimulate ovulation in the pseudopregnant rat by the administration of clinically effective ovulationinducing agents.

\section{MATERIAL AND METHODS}

The experiments were carried out with clomiphene citrate $(1-p(\beta$-diethylaminoethoxy)-phenyl-1,2-diphenyl-2-chlorethylene), cyclofenil(bis-( $p$-acetoxyphenyl)cyclohexilidenemethan), stilboestrol $\left(4,4^{\prime}\right.$-dihydroxy- $\alpha, \beta$-diethylstilbene), and epimestrol (3-methoxy-16 $\alpha, 17 \alpha$-dihydroxyoestra-1,3,5 (10)-triene). The latter compound has recently been shown in clinical trials to be of promise in the treatment of anovulation in women (Schmidt-Elmendorff, Gerteis \& Kaiser, 1969).

The animals used were 558 Wistar rats of 180 to $200 \mathrm{~g}$ body weight, whose oestrous cycle was of 5 days' length. They were kept under standard conditions with no limit placed on the supply of food and water, and under $14 / 10 \mathrm{hr}$ lighting conditions as described by Everett (1948). Vaginal smears were taken daily until constancy of the vaginal cycle was assured. Pseudopregnancy was induced on the day of oestrus by application of 9 volts d.c. for several seconds to the vaginal walls and the uterine cervix by means of a specially constructed double-barrel electrode. The day the electric shock was applied was considered to be Day 0 of pseudopregnancy.

Preliminary experiments had shown that more than $90 \%$ of the animals treated by this method would react with deciduoma formation when one of the uterine horns was subjected to trauma at noon on Day 4 of pseudopregnancy. The test substances were administered by gastric gavage in a volume of $1 \mathrm{ml}$ of propylene glycol, except for clomiphene, which was given as an aqueous solution.

All experiments were carried out with two control groups, one of which remained untreated, while the second one received the appropriate solvent. A preliminary experiment was carried out for each test substance to determine the minimum effective dose to prevent conception. Normal cyclic rats were used, which received various doses of the compounds for 12 subsequent days. Groups of three females were caged with one male rat of proven fertility from Days 2 to 12 of the experiment. The administration of the test substances was continued without consideration of eventual foeto-toxic or anti-implantation effects even when mating had taken place. Daily vaginal smears were obtained. The females were separated from the males on Day 13 of the experiment and killed on Day 21 to ascertain the number and conditions of implantation sites.

The general design of the main experiments was as follows:

In a first set of experiments, the test substances were administered over a 2-day period at various times of pseudopregnancy as described by Watnick et al. (1966). Groups of six or twelve pseudopregnant rats were treated with different doses of the test substances on Days 2 and 3,3 and 4, 4 and 5, or 6 and 7 between 10.00 and 12.00 hours. On Days 3 and 7 respectively, the doses of the test substances were given twice in accordance with the experimental 
design by Watnick et al. (1966), once between 10.00 and 12.00 hours and again between 15.00 and 16.00 hours.

Beginning on the 2nd day of drug administration, the animals were caged for 4 days with male rats of proven fertility. Daily vaginal smears were obtained, and the stage of the cycle and the presence of spermatozoa were recorded. Three days after discontinuation of the drug administration, the right Fallopian tube was removed through a dorso-lateral incision under light ether anaesthesia and examined for the presence of ova. On Day 11 of pseudopregnancy, the animals were killed, and the number and condition of implantation sites present in the contralateral uterine horn were recorded.

A. 2-day treatment

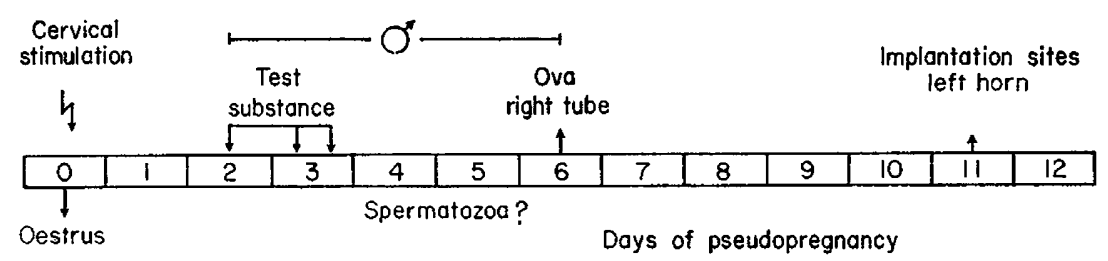

B. Continuous treatment

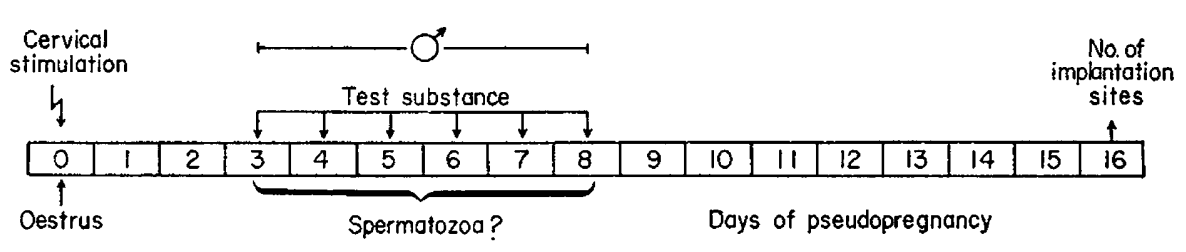

TEXr-FIG. 1. Induction of ovulation in pseudopregnant rats.

In a further set of experiments, the test substances were applied daily from Day 3 to Day 8 of pseudopregnancy, or until mating had taken place. When a female had mated, treatment was discontinued to prevent postovulatory contraceptive activity of the compound. The right Fallopian tube was not removed in those experiments. The animals were killed on Day 16 after the induction of pseudopregnancy, and the number and condition of implantation sites in both uterine horns were determined (Text-fig. 1).

Values for groups of six or more animals were given as group means \pm S.E.M. The statistical test was the $\chi^{2}$-test, using Fisher \& Yates (1953) statistical tables of significance levels.

\section{RESULTS}

Determination of the minimally effective doses of ooulation inducers for prevention of conception

The results of this experiment are shown in Table 1 . It was found that 0.08 $\mathrm{mg} / \mathrm{kg}$ clomiphene, and $2.5 \mathrm{mg} / \mathrm{kg}$ epimestrol would prevent conception. Gyclofenil had no apparent effect on ovulation and conception, even at the 
higher test dosage of $50 \mathrm{mg} / \mathrm{kg}$. At this dosage level, nidation sites were still identifiable but were partially resorbed. When epimestrol was used, implantation sites were found after administration of 1.0 and $0.25 \mathrm{mg} / \mathrm{kg}$ but the uteri were hyperaemic and distended by serous fluid. Stilboestrol was not found to inhibit ovulation and conception at the doses tested.

\section{Induction of ovulation in the pseudopregnant rat}

Two-day treatment. The results obtained with a 2-day application of the test substances at various times of pseudopregnancy are summarized in Table 2. The doses were chosen on the basis of the previously determined pregnancypreventing doses.

Only two out of a total of forty-eight untreated or solvent-treated control animals showed evidence of ovulation and pregnancy, respectively.

TABLE 1

DETERMINATION OF MINIMUM EFFECTIVE DOSE FOR THE PREVENTION OF PREGNANCY

\begin{tabular}{l|c|c|c|c|c}
\hline \multicolumn{1}{c|}{ Test substance } & $\begin{array}{c}\text { Treatment } \\
(\mathrm{mg} / \mathrm{kg} / \text { day })^{*}\end{array}$ & $\begin{array}{c}\text { No. of rats } \\
\text { treated }\end{array}$ & Matings & Conceptions & $\begin{array}{c}\text { No. of implantation } \\
\text { sites/rat } \$\end{array}$ \\
\hline Solvent control & - & 12 & 10 & 10 & 6.7 \\
Glomiphene & 0.04 & 12 & 5 & 5 & 3.9 \\
Cyclofenil & 0.08 & 12 & 0 & 0 & 0 \\
& 25.0 & 12 & 11 & 11 & 6 \\
Epimestrol & 50.0 & 12 & 8 & 8 & $\dagger$ \\
& 0.25 & 12 & 9 & 9 & 6.2 \\
Stilboestrol & 1.0 & 12 & 7 & 7 & $5.5 \$$ \\
& 2.5 & 12 & 9 & 0 & $0 \$$ \\
& 0.02 & 12 & 7 & 7 & 6.4 \\
\hline
\end{tabular}

* Treatment from Days 1 to 12 of the experiment.

$\dagger$ Macerated implantation sites.

\pm Killed on Day 21 of the experiment.

$\$$ Uterine lumen distended by serous fluid.

When clomiphene was administered at the dose of $0.08 \mathrm{mg} / \mathrm{kg} /$ day over a 2-day period, four to six out of twelve animals per group were found to have ovulated irrespective of the time of administration of the compound. When the dosage was doubled, four out of six animals were shown to have ovulated in each group. The statistical significance of these results is high $(P<0 \cdot 05)$. There were only a few matings and no pregnancies.

The results obtained by the daily application of 8 and $40 \mathrm{mg} / \mathrm{kg}$ cyclofenil respectively over a 2-day period were similar to results of clomiphene administration. There were no ovulations in the group of animals treated with 40 $\mathrm{mg} / \mathrm{kg}$ on Days 2 and 3. The ovulation rate in all other groups was, however, of the same order of magnitude as that found with clomiphene. Most of the animals which had mated were found later to be pregnant, but the nidation sites were of rather unequal size when the higher dosage was used.

The administration of $1 \mathrm{mg} / \mathrm{kg} /$ day of epimestrol proved to be ineffectual. When the daily dosage was doubled, three to four out of six animals per group 
responded with ovulation. As had been found with clomiphene, the number of matings was considerably lower than the number of animals ovulating and only one pregnancy occurred.

In confirmation of results reported by Watnick et al. (1966), the highest

TABLE 2

INDUCTION OF OVULATION IN PSEUDOPREGNANT RATS (2-DAY TREATMENT)

\begin{tabular}{|c|c|c|c|c|c|c|}
\hline Test substance & $\begin{array}{c}\text { Treatment } \\
(\mathrm{mg} / \mathrm{kg} / \text { dose })\end{array}$ & $\begin{array}{l}\text { Days of } \\
\text { treatment }\end{array}$ & $\begin{array}{c}\text { No. of } \\
\text { rats treated }\end{array}$ & Matings & Ovulations & Pregnancies \\
\hline Control untreated & & $\begin{array}{l}2+3^{*} \\
3+4 \\
4+5 \\
6+7^{*}\end{array}$ & $\begin{array}{l}24 \\
24 \\
24 \\
24\end{array}$ & $\begin{array}{l}0 \\
1 \\
0 \\
0\end{array}$ & $\begin{array}{l}0 \\
1 \\
0 \\
0\end{array}$ & $\begin{array}{l}0 \\
1 \\
0 \\
0\end{array}$ \\
\hline Solvent control & & $\begin{array}{l}2+3^{*} \\
3+4 \\
4+5 \\
6+7^{*}\end{array}$ & $\begin{array}{l}6 \\
6 \\
6 \\
6\end{array}$ & $\begin{array}{l}0 \\
0 \\
0 \\
0\end{array}$ & $\begin{array}{l}0 \\
1 \\
0 \\
1\end{array}$ & $\begin{array}{l}0 \\
0 \\
0 \\
0\end{array}$ \\
\hline Clomiphene & 0.08 & $\begin{array}{l}2+3^{*} \\
3+4 \\
4+5 \\
6+7^{*}\end{array}$ & $\begin{array}{l}12 \\
12 \\
12 \\
12\end{array}$ & $\begin{array}{l}1 \\
1 \\
0 \\
1\end{array}$ & $\begin{array}{l}6 \dagger \\
4 \\
5 \dagger \\
4 \dagger\end{array}$ & $\begin{array}{l}0 \\
0 \\
0 \\
0\end{array}$ \\
\hline Clomiphene & $0 \cdot 16$ & $\begin{array}{l}2+3^{*} \\
3+4 \\
4+5 \\
6+7^{*}\end{array}$ & $\begin{array}{l}6 \\
6 \\
6 \\
6\end{array}$ & $\begin{array}{l}0 \\
0 \\
0 \\
0\end{array}$ & $\begin{array}{l}4 \dagger \\
4 \dagger \\
4 \dagger \\
4 \dagger\end{array}$ & $\begin{array}{l}0 \\
0 \\
0 \\
0\end{array}$ \\
\hline Cyclofenil & $8 \cdot 0$ & $\begin{array}{l}2+3^{*} \\
3+4 \\
4+5 \\
6+7^{*}\end{array}$ & $\begin{array}{l}6 \\
6 \\
6 \\
6\end{array}$ & $\begin{array}{l}0 \\
4 \\
1 \\
0\end{array}$ & $\begin{array}{l}4 \dagger \\
5 \dagger \\
4 \dagger \\
4 \dagger\end{array}$ & $\begin{array}{l}0 \\
4 \\
1 \\
0\end{array}$ \\
\hline Cyclofenil & $40 \cdot 0$ & $\begin{array}{l}2+3^{*} \\
3+4 \\
6+7^{*}\end{array}$ & $\begin{array}{l}6 \\
6 \\
6\end{array}$ & $\begin{array}{l}1 \\
3 \\
3\end{array}$ & $\begin{array}{l}0 \\
4 \dagger \\
3 \dagger\end{array}$ & $\begin{array}{l}0 \\
3 \\
2\end{array}$ \\
\hline Epimestrol & $1 \cdot 0$ & $\begin{array}{l}2+3^{*} \\
3+4 \\
4+5 \\
6+7^{*}\end{array}$ & $\begin{array}{l}6 \\
6 \\
6 \\
6\end{array}$ & $\begin{array}{l}1 \\
0 \\
0 \\
0\end{array}$ & $\begin{array}{l}2 \\
2 \\
0 \\
0\end{array}$ & $\begin{array}{l}1 \\
0 \\
0 \\
0\end{array}$ \\
\hline Epimestrol & $2 \cdot 0$ & $\begin{array}{l}2+3^{*} \\
3+4 \\
4+5 \\
6+7^{*}\end{array}$ & $\begin{array}{l}6 \\
6 \\
6 \\
6\end{array}$ & $\begin{array}{l}2 \\
0 \\
0 \\
2\end{array}$ & $\begin{array}{l}4 \dagger \\
4 \dagger \\
4 \dagger \\
3 \dagger\end{array}$ & $\begin{array}{l}0 \\
0 \\
0 \\
0\end{array}$ \\
\hline Stilboestrol & 0.02 & $\begin{array}{l}2+3^{*} \\
3+4 \\
4+5 \\
6+7^{*}\end{array}$ & $\begin{array}{l}6 \\
6 \\
6 \\
6\end{array}$ & $\begin{array}{l}3 \\
1 \\
4 \\
2\end{array}$ & $\begin{array}{l}4 \dagger \\
4 \dagger \\
4 \dagger \\
4 \dagger\end{array}$ & $\begin{array}{l}2 \\
1 \\
2 \\
2\end{array}$ \\
\hline Stilboestrol & 0.04 & $\begin{array}{l}2+3^{*} \\
3+4 \\
4+5 \\
6+7^{*}\end{array}$ & $\begin{array}{l}6 \\
6 \\
6 \\
6\end{array}$ & $\begin{array}{l}3 \\
2 \\
3 \\
5\end{array}$ & $\begin{array}{l}3 \dagger \\
5 \dagger \\
4 \dagger \\
5 \dagger\end{array}$ & $\begin{array}{l}3 \\
0 \\
0 \\
0\end{array}$ \\
\hline
\end{tabular}

* On this day, the dose was administered twice.

+ Significant difference from solvent control $(P<0.05)$.

ovulation rate was found when stilboestrol was used. At each dosage level, the number of animals ovulating was highly significant when compared to controls, but not all of these animals mated and conceived.

Continuous treatment. The results of continuous administration of the test substances from Day 3 to Day 8 of pseudopregnancy, or until mating had 
occurred, are shown in Table 3 . When $0.16 \mathrm{mg} / \mathrm{kg} /$ day clomiphene was administered, nine out of twelve animals mated but none conceived. Ten out of twelve animals treated with cyclofenil at the dosage level of $8 \mathrm{mg} / \mathrm{kg} /$ day and seven out of twelve treated with $40 \mathrm{mg} / \mathrm{kg} /$ day mated. Almost all of these animals conceived but after application of the higher dosage, only necrotic implantation sites were found. In contrast to the results obtained by 2-day treatment with epimestrol, the continuous administration of $2 \mathrm{mg} / \mathrm{kg} /$ day was followed by pregnancy in eight out of twelve animals. The highest pregnancy rate was observed after application of stilboestrol but the number of implantation sites was considerably below that of the controls.

TABLE 3

INDUCTION OF OVULATION IN PSEUDOPREGNANT RATS (CONTINUOUS TREATMENT)

\begin{tabular}{|c|c|c|c|c|c|c|}
\hline Test substance & $\begin{array}{c}\text { Treatment } \\
(\mathrm{mg} / \mathrm{kg} / \mathrm{day})\end{array}$ & $\begin{array}{c}\text { Days of } \\
\text { treatment* }\end{array}$ & $\begin{array}{c}\text { No. of rats } \\
\text { treated }\end{array}$ & Matings & Pregnancies & $\begin{array}{l}\text { Average no. of } \\
\text { implantations/rat }\end{array}$ \\
\hline Solvent control & - & $\begin{array}{c}3 \text { to } 8 \\
(3 \text { to } 8)\end{array}$ & 12 & 2 & 0 & 7 \\
\hline \multirow[t]{2}{*}{ Clomiphene } & & $\begin{array}{l}3 \text { to } 8 \\
(5 \cdot 3)\end{array}$ & 12 & 5 & 0 & 0 \\
\hline & $0 \cdot 16$ & $\begin{array}{l}3 \text { to } 8 \\
(4 \cdot 0)\end{array}$ & 12 & 9 & 0 & 0 \\
\hline \multirow[t]{2}{*}{ Cyclofenil } & $8 \cdot 0$ & $\begin{array}{l}3 \text { to } 8 \\
(4 \cdot 2)\end{array}$ & 12 & 10 & 9 & $4 \cdot 9$ \\
\hline & $4 \cdot 0$ & $\begin{array}{l}3 \text { to } 8 \\
(4 \cdot 3)\end{array}$ & 12 & 7 & 7 & $\dagger$ \\
\hline \multirow[t]{2}{*}{ Epimestrol } & & $\begin{array}{c}3 \text { to } 8 \\
(5 \cdot 3)\end{array}$ & & & 4 & \\
\hline & $2 \cdot 0$ & $\begin{array}{l}3 \text { to } 8 \\
(4 \cdot 7)\end{array}$ & 12 & 8 & 7 & $4 \cdot 9$ \\
\hline \multirow[t]{2}{*}{ Stilboestrol } & & $\begin{array}{l}3 \text { to } 8 \\
(3 \cdot 7)\end{array}$ & 12 & 9 & 9 & $2 \cdot 3$ \\
\hline & 0.04 & $\begin{array}{l}3 \text { to } 8 \\
(3 \cdot 0)\end{array}$ & 12 & 11 & 11 & $1 \cdot 8$ \\
\hline
\end{tabular}

* Average number of treatment days before mating are given in parentheses.

$\dagger$ Macerated foetuses.

\section{DISCUSSION}

The results of the present study show unequivocally that the pseudopregnant rat can be made to ovulate in substantial numbers when inducers of ovulation, such as clomiphene and related compounds, are used in proper doses. The failure of Watnick et al. (1966) to find a significant number of ova after 2-day treatment with clomiphene was probably due to the experimental design of their study. In the experiments reported here, the oviduct was removed and searched for the presence of ova 3 days after the discontinuation of the test substance. Watnick et al. (1966) looked for the presence of ova before this. In preliminary experiments using this approach, we were unable to recover any ova. Concerning the effects of cyclofenil and stilboestrol, our data confirmed the earlier report by 
these authors. Epimestrol, whose clinical effectiveness is lower than that of clomiphene and more like that of cyclofenil (Schmidt-Elmendorff et al., 1969), was found to be a rather effective inducer of ovulation in the pseudopregnant rat. It could be shown that eight out of twelve animals ovulated upon administration of $2 \mathrm{mg} / \mathrm{kg} /$ day from Day 3 to Day 8 of pseudopregnancy, and seven of these animals conceived. Such a finding indicates that this compound appears to have a different mode of action from the other inducers of ovulation. In contrast to clomiphene, cyclofenil and stilboestrol, its primary site of action seems to be the ovary (Hammerstein, 1969, personal communication). There is no discernible effect of this compound upon the release of FSH and LH from the pituitary or the hypothalamic content of the respective releasing factors (Baier \& Taubert, 1969b).

The disparity between the rates of ovulation, matings and pregnancies was probably due to different effects of the compounds upon various parameters of the reproductive process. Davidson, Wada \& Segal (1965) assumed that clomiphene had a lytic or toxic effect upon the rat blastocyst, but Prasad \& Kalra (1967) recovered viable blastocysts from clomiphene-treated pregnant rats. The blastocysts could be transferred to foster-mothers and brought to implantation. These authors presumed that the antifertility effect of clomiphene depended upon an increase of uterine motility, expulsion of the blastocysts, or an anti-oestrogenic or antihistaminic action, which would prevent preimplantation changes in the uterus.

Gyclofenil was reported by Einer-Jensen (1965) to interfere with deciduoma formation when doses above $16 \mathrm{mg} / \mathrm{kg} /$ day were given to pregnant rats. In confirmation of this, only partially resorbed and degenerated implantation sites were found in animals treated with $40 \mathrm{mg} / \mathrm{kg} /$ day of this compound. An antifertility effect of stilboestrol was reported by Burdick \& Whitney (1938) and Burdick \& Emerson (1939), who observed this compound to hasten tubal passage of the fertilized ova and to promote regression of the corpus luteum.

The validity of using the pseudopregnant rat as a model for testing potential inducers of ovulation may be open to question. Pseudopregnancy in the rat is usually characterized by the presence of corpora lutea which remain functional for longer periods of time than in cyclic animals. In this study, pseudopregnant rats were chosen as models of anovulation rather than animals in persistent oestrus induced by continuous lighting, injection of androgens in the postnatal period or hypothalamic lesions. Animals subjected to these treatments appear to have their endocrine balance altered to a considerable extent. It had been previously reported by Roy, Greenblatt \& Mahesh (1964) that clomiphene did not induce luteinization of the ovaries of androgen-sterilized rats, and Maric, Matsuyama \& Lloyd (1965) could not induce di-oestrus by the injection of clomiphene into rats which had been put in persistent oestrus by continuous lighting. Contrary to this, it was reported recently by Döcke (1969) that ovulation could be induced in rats in which a chronic state of anovulation had been set up by administration of testosterone propionate on the 3rd postnatal day, by continuous lighting, or by an electrolytic lesion sited in the median anterior hypothalamus. In this study, luteinization of ovarian tissue transplanted into the anterior chamber of the eye was observed after application of relatively 
high doses ( 2 to $10 \mathrm{mg} / \mathrm{kg} /$ day for 5 days) of clomiphene. These doses were considerably higher than the ones used in the present study. Similarly, Hohlweg \& Mayer (1970) induced corpus luteum formation in immature female rats by s.c. injection of 25 to $75 \mu \mathrm{g}$ of clomiphene/rat as a single injection. The rat in persistent oestrus can probably be considered to be a closer equivalent of the anovulatory human female with polycystic ovaries than the pseudopregnant rat. Further studies will be required to elucidate whether the doses, which were shown to be highly effective in stimulating ovulation in the pseudopregnant rat would be as effective for rats in persistent oestrus.

There was no apparent difference in response to drugs inducing ovulation when these were given over 2-day periods from Day 2 to Day 7 of rat pseudopregnancy. Since it was not the object of the present study to investigate at what stage of pseudopregnancy the rat would respond optimally to a given dose of such drugs, the dosage scheme of Watnick et al. (1966) was followed. These authors doubled the dose on Day 3 and Day 7 of pseudopregnancy, as it was felt that this would lead to more uniform results. According to De Feo (1963) and van Rees \& de Groot (1965), the pituitary gonadotrophin content of the pseudopregnant rat is low on Days 2 and 3 when compared to Day 4. On Day 7, it is higher but there is little release. It was assumed, therefore, that the administration of larger amounts of these compounds on these specific days would yield more uniform responses.

The results reported here indicate clearly that, at certain doses, all ovulation inducers, which are clinically effective will also induce ovulation in the pseudopregnant rat. It could be argued that their primary action would be to increase mating behaviour which could trigger ovulation. This appears highly unlikely, as the number of animals ovulating by far exceeded the number of matings. It also became apparent that there was no correlation between the potency of compounds in stimulating ovulation in the pseudopregnant rat and the anovulatory human female.

\section{AGKNOWLEDGMENTS}

We wish to acknowledge gratefully the generous supply of clomiphene by Professor Dr R. Garten (Merrel, Gross Gerau, Germany), of cyclofenil by Mr T. Leideman of Ferrosan AB, Malmö, Sweden, and of epimestrol by $\mathrm{Dr}$ Kopera (N.V. Organon, Oss, Holland). The stilboestrol used was a gift of Farbwerke Bayer, Leverkusen, Germany. This study would not have been possible without the technical assistance of Mrs E. May and Mr R. Kessler.

\section{REFERENCES}

Bater, H. \& TAUBeRT, H.-D. (1969a) The effect of clomiphene upon plasma Fsh-activity and hypothalamic FSH-RF content in ovariectomized estrogen-progesterone blocked rats. Endocrinology, 84, 946.

Baier, H. \& TAUBERT, H.-D. (1969b) Investigations on the effects of epimestrol and stilboestrol upon the release of FSH and LH. Horm. Metab. Res. 1, 309.

Burdick, H. O. \& Emerson, B. (1939) Repression and resorption of the corpora lutea of early pregnancy following injections of testosterone propionate. Endocrinology, 25, 913.

BURDICK, H. O. \& WHITNEY, R. (1938) Acceleration of rate of passage of fertilized ova through fallopian tubes of rabbits by massive injections of estradiol-benzoate. Endocrinology, 22, 631 . 
Davidson, O. W., WadA, K. \& Skgal, S. J. (1965) Effects of clomiphene at different stages of pregnancy in the rat. Fert. Steril. 16, 195.

De Feo, V. J. (1963) Temporal aspect of uterine sensitivity in the pseudopregnant or pregnant rat. Endocrinology, 72, 305.

Döcke, F. (1969) Ovulation-inducing action of clomiphene citrate in the rat. F. Reprod. Fert. 18, 135.

EINER-JENSEN, N. (1965) F-6066, a non-steroidal compound with pronounced effects on the reproductive system. Acta pharmac. tox. 23, 365.

Everetr, J. W. (1948) Progesterone and estrogen in the experimental control of ovulation time and other features of the estrous cycle in the rat. Endocrinology, 43, 389.

Fisher, R. A. \& YATEs, F. (1953) Statistical tables for agricultural, biological and medical research. Oliver \& Boyd, Edinburgh.

HohlwEG, W. \& MAYER, H. G. K. (1970) Experimentelle und klinische Untersuchungen über den Einfluss von Clomiphen und Gestagenon auf die gonadotrope Funktion des Hypophysenvorderlappens. Bull. schweiz. Akad. med. Wiss. 25, 264.

Igarashi, M., Ibuki, Y., Kubo, H., Kamioka, J., Yokota, N., Ebara, Y. \& Matsumoto, S. (1967) Mode and site of action of clomiphene. Am. F. Obstet. Gynec. 97, 120.

Maric, D. K., Matsuyama, E. \& Lloyd, C. W. (1965) Gonadotrophin content of pituitaries of rats in constant estrus induced by continuous illumination. Endocrinology, 77, 529.

Prasad, M. R. N. \& Kalra, S. P. (1967) Mechanism of anti-implantation action of clomiphene. 7. Reprod. Fert. 13, 59.

Roy, S., Greenblatt, R. B. \& MAHesh, V. B. (1964) Effects of clomiphene and intrasplenic ovarian autotransplantation on the anovulatory cystic ovaries of rats having androgen-induced persistent estrus. Fert. Steril. 15, 310.

Schmidt-ElmendorfF, H., Gerteis, W. \& Kaiser, E. (1969) Vergleichende Untersuchungen von drei oral wirksamen Ovulationsauslösern. 37. Vers. Deutsche Ges. Gyn. Sept. 20-24, 1968. Travemünde. J. F. Bergmann, München.

TAUbert, H.-D. \& BAIER, H. (1969) Plasma rsh activity and hypothalamic FSH-releasing factor content in ovariectomized rats following intravenous injection of Sexovid (Compound F 6066). Endocrinologia exber. 3, 123.

TAubert, H.-D., Kessler, R., Busch, G. \& Werner, H.-J. (1970) The effect of clomiphene and cyclofenil upon pituitary LH and hypothalamic LH-releasing factor content in the female rat. Experientia, 26, 97.

van REes, G. P. \& DE GRoor, C. A. (1965) Secretion of FSH and LH in the pseudopregnant rat. Acta endocr., Copenh. 49, 370.

Watnick, A. S. \& NeRI, R. O. (1968) Biological properties of three ovulation inducers, stilboestrol, clomiphene and F 6066. Acta endocr., Copenh. 59, 611.

WATNICK, A. S., TABACHNIK, I. A. \& NERI, R. O. (1966) Biological activities of some ovulation inducers. 48th Meeting, The Endocrine Society, Chicago, June 20-22, p. 130. 